\title{
DNA PROCESSING CONTEMPLATED IN THE CRIMINAL LAW (FORENSIC PROCEDURES) AMENDMENT ACT 37 OF 2013 AND THE CONSTITUTIONAL RIGHT TO PRIVACY
}

\author{
Izette Knoetze
}

LLB LLM LLD

Legal Researcher, Legal Aid South Africa

Adjunct Research Fellow, Law, Science and Justice Research Niche Area, University of Fort Hare Attorney of the High Court of South Africa

\section{Lilla Crouse}

Bluris LLB

Senior Litigator, Legal Aid South Africa

Adjunct Professor, Department of Public Law

Nelson Mandela Metropolitan University

Port Elizabeth

Advocate of the High Court of South Africa

\section{SUMMARY}

The article focuses on the provisions of the Criminal Law (Forensic Procedures) Amendment Act 37 of 2013, which established the National Forensic DNA Database (NFDD) of South Africa. The implications of DNA taking, retention, and profiling on an individual's constitutional rights are discussed with special reference to the provisions of the Protection of Personal Information Act 4 of 2013 (POPIA). The value of DNA evidence in combating crime is not disputed. Policies relating to the parameters of the database and the duration of DNA storage are also highlighted. It is submitted that the different categories of expungement of DNA samples and profiles raise constitutional issues. The article also deliberates whether there is adequate awareness of rights and adequate resources to ensure the proper destruction or expungement of DNA samples. Although the writers are prima facie of the opinion that the individual's right to privacy is not violated by the abovementioned Acts, only time will tell whether this opinion is correct. 


\section{$1 \quad$ INTRODUCTION}

DNA profiling ${ }^{1}$ began in England with Alec Jeffreys's accidental discovery that variations in our DNA could be used to create unique and identifying deoxyribonucleic acid or DNA profiles or DNA "fingerprints". 2

Profiling can be defined as the use of private information to place private behaviour under scrutiny. It has two main components, namely the generation of a profile and the application thereof.

Originally, DNA profiling was used to bolster cases against suspects by demonstrating that the sample collected from a crime scene matched the DNA profile of the suspect. Kayser ${ }^{3}$ notes that forensic DNA analysis, the identification of persons via short tandem repeat (STR) profile matching of unknown evidence material with reference material from known persons, has been considered the gold standard in forensic sciences. Collecting deoxyribonucleic acid (DNA) from crime scenes and individuals is now regarded as a critical element of effective criminal investigation and prosecution. ${ }^{4}$ The collection of a bodily sample may be a significant intrusion to bodily integrity, particularly when collection is non-consensual, or where reasonable force is used to collect the sample. DNA profiling raises constitutional and privacy concerns because the maintenance of a DNA databank involves the collecting and retaining of genetic samples from a select group of individuals. It may be necessary to protect an individual's constitutional rights by setting limits on the collection, retention and use of DNA material.

Whether DNA is held as a sample or profile may be relevant to privacy concerns. A sample contains a wider range of intimate genetic information. Although policies in some countries limit the extent of information that may be determined from the DNA sample, the right to privacy is still affected by profiles' retention, given the substantial amounts of unique personal data contained in them, including information about familial relationships and ethnic origin.

This article will attempt to address the implications of DNA taking and retention on the constitutional right to privacy in South Africa. In doing so, the South African situation will be compared to other jurisdictions.

It focuses on the provisions of the Criminal Law (Forensic Procedures) Amendment Act 37 of 2013, which established the National Forensic DNA

1 Wehunt "Drawing the Line: DNA Databasing at Arrest and Sample Expungement" 201329 4 Georgia State University LR 1063 1070. A DNA profile is not the sample, which is the actual physical specimen originally taken from the individual, but rather a simple series of numbers that represent the DNA sequence. Once the DNA profile is created from a collected sample, it is of little value unless it can be catalogued and compared with other profiles from crime scenes.

2 Suter "All in the Family: Privacy and DNA Familial Searching" 2010 23(2) Harvard Journal of Law \& Technology 309313.

3 "Forensic DNA Phenotyping: Predicting Human Appearance from Crime Scene Material for Investigative Purposes" 2015 Forensic Science International: Genetics http://www.fsigenetics.com/articles/S1872-4973(15)00032-0/pdf (accessed 2015-05-20) 1.

4 Campbell and Lynch "Competing Paradigms? The Use of DNA Powers in Youth Justice" 2012 http://yjj.sagepb.com/content/12/1/3 (accessed 2015-05-06). 
Database (NFDD) of South Africa, and addresses the implications of DNA taking and retention on the individual's constitutional rights in South Africa. DNA processing and the implications thereof on the individual's privacy are discussed in light of the provisions of the Protection of Personal Information Act 4 of 2013 (POPIA).

The value of DNA evidence in combating crime is not disputed. Policies relating to the parameters of the database and the duration of DNA storage are discussed in this article.

The expungement of DNA samples and profiles raises constitutional issues, mostly concerning the different categories of expungement and whether there is adequate awareness of rights and adequate resources to ensure proper destruction or expungement of DNA samples. ${ }^{5}$

\section{LEGISLATION PERTAINING TO DNA DATABASES}

Despite points of commonality, some notable differences exist between current laws on non-conviction. ${ }^{6}$ DNA databases in a number of commonlaw countries. England and Wales may be characterised as occupying one end of the spectrum in so far as their policies until 2011 were the most permissive, while Canada maintains the most restrictive laws. ${ }^{7}$

According to Campbell, 8 the United Kingdom's National DNA Database (NDNAD) was set up in 1995 and contains genetic material gathered from all over the UK. Proportionately speaking, the NDNAD is the largest of its kind in the world and contained 7.39 per cent of the UK population in 2009, while most recent figures indicate almost nine per cent coverage. Since 1995, the genetic information from DNA samples added to this database contained the profiles of 5.7 million people (although some profiles are duplicates). The database holds 450000 DNA profiles from crime scenes. As of June 2012, the Northern Ireland DNA Database (NIDNAD) included the DNA profiles of 123044 known persons. DNA profiles uploaded on to the NIDNAD are also loaded on to the NDNAD, although the retention of Northern Irish DNA profiles on this database is governed by the law and policy applicable in Northern Ireland. ${ }^{9}$ In 2013, as part of the Protection of Freedoms Act, the database was pruned in order to remove the details of innocent people. A total number of 1.7 million profiles of adults and children who had not been convicted of any crime was deleted. ${ }^{10}$

Suter 2010 23(2) Harvard Journal of Law \& Technology 362.

6 Campbell "Non-Conviction' Criminal Databases and Justice: A Comparative Analysis" 2011 J.C.C.L. https://www.academia.edu/606506/_Non-Conviction_DNA_Databases_and_Crimi nal_Justice_A_Comparative_Analysis (accessed 2015-05-06) 56 defines "non-conviction DNA" as "shorthand for storage of DNA which is not dependent on a criminal conviction and occurs regardless of the results of a criminal investigation or prosecution".

7 Campell https://www.academia.edu/606506/_Non-Conviction_DNA_Databases_and_Crimi nal_Justice_A_Comparative_Analysis 6 (accessed 2015-05-06).

8 Ibid.

9 Gaughran v Chief Constable of the Police Service of Northern Ireland [2015] UKSC 29 par 14 https://www.supremecourt.uk/cases/docs/uksc-2013-0090-judgment.pdf (accessed 2015-05-18).

10 Shaw "Can We Still Rely on DNA Sampling to Crack Crime?" 5 May 2015 http://www.bbc.com/news/uk-32546186 (accessed 2015-05-06). 
A DNA database was established in New Zealand in 1995. This was followed at federal level in the US with the establishment of the Combined DNA Index System (CODIS) and the National DNA Index System (NDIS) in 1998. ${ }^{11}$ The Canadian National DNA Data Bank has been in place since 2000, and the Australian National Criminal Investigation DNA Database (NCIDD) was established in 2001.

\section{Position in New Zealand}

The primary legislation in New Zealand is the Criminal Investigations Bodily Samples (CIBS) Act 1995, which has been amended regularly since its enactment. This Act provides for a national DNA database on which DNA profiles from voluntary and compelled samples may be stored. At the end of December 2010, there were approximately 115500 profiles on the database. $^{12}$

\section{Position in Scotland}

Scotland has a separate legal regime to the rest of the UK for DNA collection and retention, and has its own DNA database, established in 1995. Profiles derived from these DNA samples are exported to the UK-wide NDNAD and may be checked against those collected from persons in England, Wales and Northern Ireland. At the end of 2007, the number of profiles from individuals on the NDNAD was $225534 .^{13}$

As seen from the above, a large number of profiles are stored on DNA databases worldwide. One is often tempted to make the assumption that the more DNA profiles are held by the police, the greater their chances of discovering the identity of those who commit future crime. This way of thinking is an illustration of the tension between the societal need to combat crime effectively by bringing offenders to book and the individual's constitutional right to privacy.

\section{Position in South Africa}

The Criminal Law (Forensic Procedures) Amendment Act 37 of $2013^{14}$ was assented to by the State President on 27 January 2014 and came into operation on 31 January 2015, with the exception of section 2 (to the extent that it inserts section $36 \mathrm{D}(1)$ in the Criminal Procedure Act 51 of 1977). ${ }^{15}$

Crime scene samples include samples containing DNA taken from the crime scene, as well as bodily samples taken from victims and deceased persons. Taking samples from victims should be done in accordance with the provisions of section 36E of the Criminal Procedure Act 51 of 1977. In

\footnotetext{
Campbell 2011 https://www.academia.edu/606506/ Non-Conviction DNA Databases and_Criminal_Justice_A_Comparative_Analysis 6 (accessed 2015-05-06).

12 Campbell and Lynch 2012 http://yjj.sagepb.com/content/12/1/3 5 (accessed 2015-05-06).

13 Campbell and Lynch 2012 http://yjj.sagepb.com/content/12/1/3 6 (accessed 2015-05-06).

14 GN 52 in GG 37268 of 2014-01-27.

15 Proc R594 in GG 38376 of 2014-12-30.
} 
terms of this section, an authorised person ${ }^{16}$ should request the victim to agree that a bodily sample be taken, either by buccal swab, ${ }^{17}$ or an intimate sample ${ }^{18}$ in cases of sexual offences. Intimate samples may only be taken by a medical practitioner ${ }^{19}$ or a registered nurse in accordance with strict adherence to "decency and order". ${ }^{20}$ Buccal samples should be taken either by an authorised person or by medical personnel who should be of the same gender as the person from whom the sample is taken. ${ }^{21}$ Furthermore, the sample must also be taken in accordance with the requirements of regulations made by the Minister of Police, and in a designated area that is deemed to be suitable by one of the Departmental Heads of Police, Justice and Constitutional Development, or Correctional Services.

The collection of DNA samples can be divided into crime scene samples and comparator samples. Comparator samples are taken from individuals in order to populate the five indices that are set out in section 15 of the Act, ${ }^{22}$ namely:

(a) an Arrestee Index; ${ }^{23}$

(b) a Convicted Offender Index; 24

(c) an Investigative Index; 25

(d) an Elimination Index; and ${ }^{26}$

(e) a Missing Persons and Unidentified Human Remains Index. ${ }^{27}$

Each of these indices has a sub-index for children. ${ }^{28}$ Regulations ${ }^{29}$ regarding the taking of samples, the safekeeping thereof and the timely transfer of the samples to the Forensic Science Laboratory are discussed elsewhere in this article.

Section $15 \mathrm{E}(\mathrm{m})$ of the Criminal Law (Forensic Procedures) Amendment Act $^{30}$ defines a forensic DNA profile as follows:

16 An authorised person can be any police official or member of the Independent Police Investigative Directorate, who is not the crime scene investigator of the specific case and has successfully completed training in terms of the National Health Act 61 of 2003 in respect of the procedure to be followed in taking a buccal swab. The authorised person must be of the same gender as the donor and the taking of the buccal swab must also comply with strict regard to decency and order. S36(b)(ii).

17 A buccal swab is defined as "a sample of cellular material taken from the inside of a person's mouth". S 36(c)(cB).

18 An intimate sample means a sample of blood or pubic hair or a sample taken from the genitals or anal orifice area of the body of a person. S 36(e)(fF).

19 A medical practitioner or nurse must be registered in terms of the National Health Act 61 of 2003. Remember that an intimate sample can only be taken by a doctor or nurse.

20 S $36 D(7)(d)$ of 51 of 1977.

21 S $36 A(3)$ and (5) of 51 of 1977.

S $15 G 3$ of the Criminal Law (Forensic Procedures) Amendment Act 37 of 2013.

S 15G3(b) of 37 of 2013.

S 15G3(c) of 37 of 2013.

S $15 G 3(d)$ of 37 of 2013.

S 15G3(e) of 37 of 2013.

S $15 \mathrm{G} 3(\mathrm{f})$ of 37 of 2013.

S $15 \mathrm{G}(4)$ of 37 of 2013

Forensic DNA Regulations, 2015. GN R207 in GG 38561 of 2015-03-13.

37 of 2013. 
"the results obtained from forensic DNA analysis on bodily samples taken from a person or a crime scene, providing a unique string of alpha numeric characters to provide identity reference: Provided that it does not contain any information on the health or medical condition or any information on the predisposition or physical information of that person other than the sex of that person".

\section{DNA COLLECTION}

Key differences exist between common-law countries in terms of the populations from whom DNA samples may be taken.

Many of the comparator jurisdictions permit DNA collection to be predicated on arrest and police discretion. In the UK, US and New Zealand, the police may collect DNA from a wide range of suspects without judicial approval. In England, Wales and Northern Ireland, a DNA sample may be taken from any individual arrested for or informed that he will be reported for a recordable offence, whether or not he is detained. ${ }^{31}$

In Canada, DNA collection may occur only in accordance with a court warrant and in relation to a suspected indictable offence, if the best interest of the administration of justice necessitates a comparison between that person's DNA and material found at a crime scene. ${ }^{32}$ Campbell ${ }^{33}$ is of the opinion that the warrant requirement in Canada for any DNA collection is preferable because of the express articulation of reasonable suspicion and judicial involvement. Judicial approval through a warrant safeguards the collection process from abuse, given the independent examination of police suspicions and reasoning which underpin the request for a bodily sample. She further notes that limiting the power to authorise DNA collection to judicial officers ensures that an adequate detachment is maintained between the investigating body and the appraiser of reasonable suspicion on which DNA collection is predicated. ${ }^{34}$

In South Africa, the Criminal Law (Forensic Procedures) Amendment Act 37 of 2013 regulates when, where, how and by whom bodily samples (that is, both intimate and buccal samples) may be taken. ${ }^{35} \mathrm{~A}$ buccal swab refers to "a sample of cellular material taken from the inside of a person's mouth". 36 An intimate sample means "a sample of blood or pubic hair or a sample taken from the genitals or anal orifice of the body of a person, excluding a buccal swab". ${ }^{37}$

The amendment to section 36A of the Criminal Procedure Act 51 of 1977 regulates the taking of samples for DNA analysis. Sections $36 \mathrm{D}(1)$ and $15 \mathrm{~J}$

31 Campbell $2011 \mathrm{https} / / \mathrm{www}$.academia.edu/606506/_Non-Conviction_DNA_Databases_ and_Criminal_Justice_A_Comparative_Analysis 8 (accessed 2015-05-06).

32 Campbell 2011 https://www.academia.edu/606506/_Non-Conviction_DNA_Databases and_Criminal_Justice_A_Comparative_Analysis (accessed 2015-05-06) $\overline{9}$.

33 Campbell $2011 \mathrm{https} / / / \mathrm{www}$.academia.edu/606506/_Non-Conviction_DNA_Databases_ and Criminal Justice A Comparative Analysis 13 (accessed 2015-05-06).

34 Campbell 2011 https://www.academia.edu/606506/_Non-Conviction_DNA_Databases and_Criminal_Justice_A_Comparative_Analysis 14 (accessed 2015-05-06).

$35 \mathrm{~S} 3 \overline{6 \mathrm{~A}}(\mathrm{CA})$ of 51 of 1977.

$36 \mathrm{~S} 36 \mathrm{~A}(\mathrm{CB})$ of 51 of 1977.

$37 \quad S 36(b)(i)$ of 51 of 1977. 
provide for the circumstances under which samples must be taken, while section $36 \mathrm{D}(2)$ provides for the circumstances when samples may be taken, and section $36 \mathrm{E}$ refers to the authorisation to take samples for investigation purposes.

The Criminal Law (Forensic Procedures) Amendment Act 37 of 2013 mandates DNA collection from all offenders post-conviction in South Africa. ${ }^{38}$ This includes profiles obtained from arrestees who have subsequently been convicted and profiles from all offenders, including those who were convicted before the Act came into operation. Collection of DNA from individuals convicted of violent crimes, such as murder and rape, and crimes which have an increased likelihood of being repeated, and DNA evidence left at the crime scene is generally accepted by most countries as sufficient justification for including such populations on a DNA database. The forensic profiles in the Convicted Offender Index must be stored on the NFDD and be retained indefinitely.

Lord Kerr, in his dissenting judgment of Gaughran v Chief Constable of the Police Service of Northern Ireland, ${ }^{39}$ noted as follows regarding the objective of indefinite retention of profiles:

"Moreover, the rational connection here must be between the objective of the detection of future criminals and the indefinite retention of the profile, fingerprints and photograph. It is not enough that retaining these items on a permanent basis might, in some vague or unspecified way, help in the detection of crime in the future. It is necessary to show that in a real, tangible sense, keeping DNA profiles, fingerprints and photographs indefinitely will assist in counteracting or detecting future crime. ... as a minimum, it must be established that retaining forever such items from all who have been convicted of recordable crime is likely to make a positive and significant contribution to the detection of future criminal activity."

It should be noted that many who have been convicted, especially of less serious, recordable offences, have never reoffended. ${ }^{40}$

\section{Mandatory collection in terms of section 36D: Pre-conviction}

An authorised person or a registered medical practitioner or registered nurse is obliged to take either buccal swabs or intimate samples from designated persons. An authorised person can be any police official or member of the Independent Police Investigative Directorate, who is not the crime scene investigator of the specific case, and who has successfully completed training in terms of the National Health Act 61 of 2003 in respect of the procedure to be followed in taking a buccal swab. ${ }^{41}$ The authorised person must be of the same gender as the donor, and the taking of the buccal swab must also comply with strict regard to decency and order. ${ }^{42}$

\footnotetext{
S 15J of 37 of 2013.

Supra par 65 https://www.supremecourt.uk/cases/docs/uksc-2013-0090-judgment.pdf.

40 Gaughran v Northern Ireland par 70 https://www.supremecourt.uk/cases/docs/uksc-20130090-judgment.pdf.

$41 \quad \mathrm{~S} 36(\mathrm{~b})$ of 51 of 1977.

42 S 36(3) of 51 of 1977.
} 
As noted earlier, the comparator samples are taken from individuals in order to populate the five indices that are provided for in section 15 of the Act. ${ }^{43}$ These indices are discussed below.

\section{Arrestee Index}

An authorised person is obliged to take samples from the following persons:

"(a) Those arrested but before appearance in court to be formally charged for a Schedule 8 offence; 44

(b) Those granted bail in respect of a Schedule 8 offence and if the buccal sample or bodily sample had not been taken during the arrest phase;

(c) Those upon whom a summons in respect of any Schedule 8 offence has been served;

(d) Those whose names appear on the National Register of Sex Offenders; or

(e) Those who are charged or convicted by a court in respect of any offence which the Minister by notice in the Government Gazette has declared as an offence for the purposes of this subsection."

The Act requires that an authorised person taking the sample (buccal swab) must be of the same gender. An additional requirement is that it should be taken "with strict regard to decency and order". The authorised person must take the buccal swab in a designated area "deemed suitable by the Departmental Heads: Police, Justice and Constitutional Development or

3 S $15 \mathrm{G} 3$ of 37 of 2013.

44 Schedule 8 offences are: Treason, Sedition, Public violence, Murder, Any offence referred to in Part I or Part II of Schedule 1 to the Implementation of the Rome Statute of the International Criminal Court Act, 2002 (Act 27 of 2002), Culpable homicide, Rape or compelled rape as contemplated in sections 3 and 4 of the Criminal Law (Sexual Offences and Related Matters) Amendment Act, 2007 (Act 32 of 2007), respectively, Sexual assault, compelled sexual assault or compelled self-sexual assault as contemplated in s 5, 6 or 7 of the Criminal Law (Sexual Offences and Related Matters) Amendment Act, 2007 (Act 32 of 2007), respectively, Any sexual offence against a child or a person who is mentally disabled as contemplated in Part 2 of Chapter 3 or the whole of Chapter 4 of the Criminal Law (Sexual Offences and Related Matters) Amendment Act, 2007 (Act 32 of 2007), respectively, Robbery, Kidnapping, Child-stealing, Assault, when a dangerous wound is inflicted, Arson, Breaking or entering any premises, whether under the common law or a statutory provision, with intent to commit an offence, Theft, whether under the common law or a statutory provision, Escaping from lawful custody, where the person concerned is in such custody in respect of any offence referred to in Schedule 1, or is in such custody in respect of the offence of escaping from lawful custody. Any -

(a) offence under the Firearms Control Act, 2000 (Act No. 60 of 2000), which is punishable with imprisonment for a period of five years or longer in terms of the said Act;

(b) offence under the Explosives Act, 2003 (Act No. 15 of 2003), which is punishable with imprisonment for a period of five years or longer in terms of the said Act;

(c) Convention offence or specified offence as defined in section 1 of the Protection of Constitutional Democracy against Terrorist and Related Activities Act, 2004 (Act No. 33 of 2004);

(d) offence of trafficking in persons as defined in section 1 of the Prevention and Combating of Trafficking in Persons Act, 2013 (Act No. 7 of 2013); or

(e) offence of torture as defined in the Prevention and Combating of Torture of Persons Act, 2013 (Act No. 13 of 2013.

Any conspiracy, incitement or attempt to commit any offence referred to in this Schedule. 
Correctional Services in their area of responsibility" and in accordance with any Development or Correctional Services in their area of responsibility" and in accordance with any regulations made by the Minister of Police. ${ }^{45} \mathrm{No}$ consent or warrant is required by this section. The Act also makes provision for the possibility of the donor to take his or her own buccal swab, under supervision of the authorised officer. ${ }^{46}$ The Forensic DNA Regulations, 2015, published in the Government Gazette ${ }^{47}$ regulates the taking of a DNA sample and provides as follows:

"2 The taking of a DNA sample

(1) The authorised person must supervise the taking of a buccal sample from a person who is required to submit such sample, and who requests to take the sample himself or herself.

(2) The DNA reference (buccal) collection kit must be used to collect the buccal sample.

(3) In the absence of a buccal sample or upon a specific request of a person from whom the sample is required, a control blood sample may be taken by a registered medical practitioner or registered nurse.

(4) The personnel protective clothing provided in the DNA reference (buccal) collection kit must be worn by the authorised person when a buccal sample is collected from any person. The personnel protective clothing provided in the DNA reference (buccal) collection kit must be disposed of by placing these items in the original packaging (pouch) of the kit, which in turn must be attached to the evidence sealing bag containing the DNA reference sample.

(5) A victim of a sexual offence must be taken to a registered medical practitioner or registered nurse for the medico-legal examination.

(6) The appropriate evidence collection kit for examining a victim of a sexual offence must be handed to the registered medical practitioner in order to collect the forensic evidence. The investigating officer must ensure that the evidence collection kits are submitted to the Forensic Science Laboratory for forensic DNA analysis as soon as possible, but in any event within 30 days after the examination.

(7) Only a registered medical practitioner or registered nurse may take intimate samples from any person.

(8) The authorised person must take the buccal sample immediately after the fingerprints of the person have been taken."

Section $36 \mathrm{D}(2)$ refers to the discretion that an authorised person has either to take a buccal sample, or to authorise the taking of an intimate sample by a doctor or nurse in respect of all offences. An authorised person is permitted to take a DNA sample from the following persons:

"(i) Those arrested but not yet formally charged in respect of any offence;

(ii) Those on bail in respect of any offence, if a buccal sample or bodily sample had not been taken upon arrest;

(iii) Those who have been served a summons for any offence;

(iv) Those named in the National Register for Sex Offenders or

S 36(5)(a) and (b) of 51 of 1977.

46 S 36D(3) of 51 of 1977.

47 The Minister of Police has, under S15AD of the South African Police Service Act 68 of 1995, made the regulations in the Schedule entitled the Forensic DNA Regulations, 2015. GNR 207 in GG 38561 of 2015-03-13. 
(v) Those charged or convicted by a court of any offence, which the Minister has by notice in the Government Gazette and after parliament has been given notice declared an offence for the purposes of this section."

\section{Investigative Index}

Section 36E provides for the taking of samples for investigative purposes. Buccal swabs may be taken on reasonable grounds when a person is suspected of having committed a Schedule 8 offence and when it is reasonably believed that the taking of a sample may exclude a person as a suspect. ${ }^{48}$ Consent or a warrant is required. According to section $36 \mathrm{E}(1)$ of the Act, an authorised person can personally take a buccal swab or supervise the taking of a DNA sample from a person or group of persons if there are reasonable grounds to suspect that (i) the person or that one or more of the persons in a group has committed a Schedule 8 offence and (ii) to believe that the buccal sample or the results thereof will be of value in the investigation by excluding or including one or more of those persons as possible perpetrators of the offence.

A person can agree only to have a sample taken if "informed consent" is given in writing after he or she has been informed of the following, namely, the manner in which the buccal sample will be taken; that he or she is under no obligation to provide a buccal sample; that the sample or the forensic DNA profile derived from it may produce evidence that might be used in a court of law; that the buccal sample taken under this section, and the forensic DNA profile derived from it, may be used only for purposes referred to in section $15 \mathrm{~F}$; and that any profile derived from a sample taken under this section will be removed within a period of three months after the case has been finalised.

Where a suspect does not consent to having a buccal sample taken in terms of section $36 \mathrm{E}(1)$, the authorised person can approach the court to issue a warrant.

Once the authorised person has obtained a warrant, it is not clear from the Act how a buccal swab can be taken from a suspect who refuses to submit to such a procedure. The Act does not indicate whether reasonable force can be used to take the sample. However, it is suggested that, if a person, who is not arrested but merely a suspect, refuses to give such a sample, the warrant should indicate what force, if any, may be used to obtain the desired sample. It must be remembered that, although section 35 of the Constitution might not be applicable, section 12(2)(b) of the Constitution provides for definite constitutional protection of such a suspect. Section 12(2) provides as follows:

48 In the matter of Van der Velden 29514/04 and $W v$ The Netherlands 20689/08 [2009] ECHR 277 the European Court of Human Rights (ECHR) noted that, while the interference at issue was relatively slight, the applicant may also reap a certain benefit from inclusion of his DNA profile in the national database in that he may thereby be eliminated rapidly from the list of persons suspected of crimes in the investigation of which material containing DNA has been found. 
"Everyone has the right to bodily and psychological integrity, which includes the right -

(a) to make decisions concerning reproduction;

(b) to security in and control over their body; and

(c) not to be subjected to medical or scientific experiments without their informed consent."

In Canada, any "necessary" force may be used to take the sample, and the blood sample need not be taken by a medical physician. ${ }^{49}$

In New Zealand, if consent to taking a bodily material is not forthcoming and thus force needs to be used, a finger-prick blood sample must be taken rather than a buccal swab, indicating some divergence in terms of political and legal perceptions of physical intrusions, given the legislation preference for the latter in non-consensual situations in the United Kingdom. ${ }^{50}$

\section{Elimination Index}

The Elimination Index ${ }^{51}$ contains samples from persons who are considered to be at risk of contaminating crime scene samples with their own DNA. The Elimination Index must include profiles from police officials involved in official crime scene duties; persons that handle and process crime scene or bodily samples; persons that deal with equipment, such as in the case of servicing and calibration of equipment used in the examination of crime scene or bodily samples; persons who enter an area where forensic DNA is examined or who, in terms of chapter $5 \mathrm{~B}$, in any way have contact with crime scene samples; and persons who are in any way involved in the production of any product used in the process of DNA analysis.

\section{Missing Persons and Unidentified Human Remains Index}

The Missing Persons and Unidentified Human Remains Index is regulated by section $15 \mathrm{M}$. This index will consist of forensic DNA profiles derived from any bodily sample of a missing or unidentified person or any bodily sample taken from unidentified human remains.

\section{DNA RETENTION AND EXPUNGEMENT}

As noted earlier, DNA profiles contain a range of intimate personal and family information, and thus retention engages and affects the right to privacy. The period of retention of the DNA profile and the expungement thereof also affect the individual's right to privacy.

4 Criminal Code of Canada, s 487.07.

50 Campbell 2011 https://www.academia.edu/606506/_Non-Conviction_DNA_Databases and_Criminal_Justice_A_Comparative_Analysis 13 (accēssed 2015-05-06).

51 S $1 \bar{L} \mathrm{~L}$ of $\mathrm{ch} 5 \overline{\mathrm{B}}$ of the South African Police Service Act 68 of 1995. 
Several states provide for retention until death. They are Austria: five years after death or 80 years of age; Denmark: two years after death or at 80 years of age; Estonia: ten years after death; Finland: ten years after death; Lithuania: 100 years after inclusion or ten years after death; Luxembourg: ten years after death; Romania: five years after death or 60 years of age, and Slovakia: 100 years after date of birth. There is little, if any, difference between retention for an indefinite period and retention until death or effectively until death. ${ }^{52}$

Different retention periods and rules exist for adults and children in various jurisdictions. These periods are discussed below.

\section{Adults}

As noted earlier, a warrant is required prior to collection, and a judge determines the retention period in Canada. Retention beyond a year requires magistrate approval in Australia. A district court judge must order retention at six-monthly intervals in New Zealand. ${ }^{53}$

Specific time frames are provided in Scotland, Australia, New Zealand and South Africa. Retention of genetic samples is permitted in Scotland after prosecution only when it does not lead to conviction and in relation only to certain sexual or violent offences. ${ }^{54}$ In Australia, the material must be destroyed as soon as practicable after 12 months of taking the sample if proceedings have not been instituted or have been discontinued, or if the person has been acquitted and no appeal is lodged, or the appeal is withdrawn, unless there is an outstanding arrest warrant for the suspect. In New Zealand, a sample must be destroyed as soon as practicable after a DNA profile is obtained from it, and records of analysis must be destroyed as soon as practicable within two months of taking the sample, if the person is not charged, if the charge is withdrawn or the person is acquitted. ${ }^{55}$ The Canadian Criminal Code provides that bodily substances taken under warrant will be destroyed "without delay" if a match is not found between the suspect's DNA and the material from the crime scene, or if the person is finally acquitted, or will be destroyed within a year if proceedings are discontinued. ${ }^{56}$ Currently, every state in the United States, as well as the Federal Bureau of Investigation, collects DNA data from persons convicted of enumerated crimes. ${ }^{57}$ In the US, the DNA Fingerprinting Act 2005 does not provide specific retention periods, but states that destruction occurs on receipt of a court order certifying that the charge has been dismissed or

52 Lord Clarke (with whom Lord Neuberger, Lady Hale and Lord Sumption concurred) noted as follows in Gaughran $v$ Chief Constable of the Police Service of Northern Ireland supra par 42 https://www.supremecourt.uk/cases/docs/uksc-2013-0090-judgment.pdf.

53 Campbell 2011 https://www.academia.edu/606506/_Non-Conviction_DNA_Databases and_Criminal_Justice_A_Comparative_Analysis 19 (accessed 2015-05-06).

54 Campbell 2011 https://www.academia.edu/606506/_Non-Conviction_DNA_Databases_ and_Criminal_Justice_A_Comparative_Analysis 17 (accessed 2015-05-06).

55 Criminal Investigations (Bodily Samples) Amendment Act 2009, s 60A.

56 Criminal Code of Canada s 487.09.

57 Werse "A Lengthy, Uncertain, and Expensive Process: A Comparison of Types of Expungement from DNA Databases of Arrestees" 2013 39(2) Rutgers Computer \& Technology LJ 282. 
resulted in an acquittal, or that no charges are being brought. ${ }^{58}$ Expungement processes differ from state to state, but generally fall into two categories: upon request, for example expungement through court order, or an application process, or automatically when the individual is acquitted or not charged. ${ }^{59}$ The majority of states uses a system that requires an application process to expunge DNA from a database, while a minority of states employs a method that allows for automatic expungement. 60

In order to commence the expungement process, California requires that arrestees file a form together with supporting documentation, such as copies of the docket or a letter from the district attorney. An applicant has to send a copy of the form to the trial court of the county where the offence occurred, the DNA laboratory, and the prosecuting attorney, as well as to provide proof of service to all these people. The court then has discretion whether or not to grant the request. If denied, the decision is not appealable. ${ }^{61}$

In order to destroy the specimen, the applicant is required to show the following, namely:

- the written request of expungement; and

- either a certified copy of the court order that dismisses the case,

- or a letter from the district attorney stating that no charges were filed or pursued;

- proof of notice to the Department of Justice and district attorney that there has been a request for expungement; and

- a court order stating there is no retrial or appeal and that it has been 180 days or more since the applicant notified the prosecuting attorney and the Department of Justice of the expungement request, and no objection to that request has been given by the prosecuting attorney.

The prosecutor, upon receipt of the petitioner's letter, determines the eligibility of the petitioner. Although the prosecutor is supposed to rely on the petitioner's criminal history in making the decision, the prosecutor's discretionary powers are extraordinarily wide. ${ }^{62}$ The DNA laboratory is then tasked to destroy the sample, as well as any searchable profile that has been entered into the database. When the laboratory expunges the profiles, the applicant receives a notice of confirmation that the process has been completed. ${ }^{63}$ Werse poses the following important question, namely: ${ }^{64}$

"If it is the defense attorney's obligation to tell the defendant about the expungement process and not the responsibility of the prosecution, it begs the question of what happens to those people who do not need attorneys or who

58 The DNA Fingerprint Act of 2005 was approved on 5 January 2006 and has been effective since 9 January 2009. The legislation has expanded the list of federal qualifying offences to individuals who are arrested or from non-US persons who are detained in the US. This legislation amended the DNA Identification Act of 1994 and requires laboratories to have an expungement policy and procedures for individuals who have had their charges withdrawn or who have been acquitted.

59 Werse 2013 39(2) Rutgers Computer \& Technology LJ 291.

60 Werse 2013 39(2) Rutgers Computer \& Technology LJ 294.

61 Werse 2013 39(2) Rutgers Computer \& Technology LJ 293.

62 Werse 2013 39(2) Rutgers Computer \& Technology LJ 291.

63 Werse 2013 39(2) Rutgers Computer \& Technology LJ 294.

64 Ibid. 
are not represented by an attorney. How are they to find out about the provisions for expungement?"

A complicated system of retention rules was introduced in England and Wales to differentiate between adults and children under 18 years, and between those convicted or cautioned as well as those who have been acquitted. A distinction also exists between petty offences and violent crimes, such as burglary, rape, murder and terrorism. The effect of DNA retention on privacy has been judged partly by the categories of persons whose DNA may be retained, the duration of retention and the form in which DNA is stored.

These amendments to the Police and Criminal Evidence Act 1984 (PACE) were introduced by the Protection of Freedoms Act 2012 in the light of the decision of the European Court of Human Rights (ECHR) in $S$ and Marper. Section 63 I of the PACE now provides that fingerprints and a DNA profile (derived from a DNA sample), taken from a person convicted of a recordable offence, may be retained indefinitely. Section $63 \mathrm{~K}$ provides as follows, namely, that (i) where a person convicted is under the age of 18 years at the time of the offence, (ii) the offence is a "minor" recordable offence (meaning an offence which neither attracts a custodial sentence of more than five years, nor is a "qualifying offence" as defined in section $65 \mathrm{~A}$, and (iii) the person has not previously been convicted of a recordable offence, the period of retention of such material may be shorter: the length of the sentence plus five years where the person concerned receives a custodial sentence of less than five years or, if no custodial sentence was given, five years from the time when the fingerprints or DNA sample were taken, as the case may be. These provisions are subject to the person not reoffending during the relevant period. If the person is convicted of another recordable offence during the relevant period, the material may then be retained indefinitely (section $63 \mathrm{~K}(5)$ ). Where the custodial sentence is five years or more, or where the offence is a "qualifying offence", the material may again be held indefinitely. Section $63 \mathrm{R}$ relates to the destruction of samples, including nonintimate samples. Section $63 \mathrm{R}(4)$ provides for the general principle that a sample must be destroyed as soon as a DNA profile has been taken from it and, in any event, within six months of the sample having being taken. As to photographs, section $64 \mathrm{~A}(4)$ of the PACE is in the same terms as article $64 \mathrm{~A}(4)$ of the 1989 Order.

In South Africa, section $15 \mathrm{Q}$ of Act 37 of 2013 provides for the retention, storage, destruction and disposal of crime scene and buccal samples. DNA samples should be destroyed within three months after a profile has been loaded onto the NFDD. The Act dictates that bodily samples and crime scene samples must be analysed and uploaded within 30 days after their arrival at the Forensic Science Laboratory, unless there is a compelling reason in terms of priorities why such samples cannot be analysed and loaded within that period. 65

In terms of Regulation 10(1), ${ }^{66}$ DNA reference samples ${ }^{67}$ and buccal samples must be destroyed within 30 days after obtaining a forensic DNA

S 15Q(1) of 37 of 2013

66 Forensic DNA Regulations, 2015. GNR 207 in GG 38561 of 2015-03-13. 
profile or after the sample has been processed by the Forensic Science Laboratory. Regulation 10(4) provides that the destruction of the buccal samples must be recorded in the laboratory case file or appropriate register. The appropriate register may be a logbook or the information system used in the laboratory to support DNA casework.

There seems to be a discrepancy between the retention periods mentioned in the Act and the Regulations. For destruction and expungement of DNA profiles, different considerations apply in respect of the different indices.

For the Arrestee Index, the profiles must be expunged within three years after the authorised officer is informed that a decision was taken not to prosecute, or was informed that the accused was acquitted at the trial, or that a conviction was set aside on appeal. Expungement would also apply where the person had been discharged at a preparatory examination, where no criminal proceedings with regard to DNA were instituted, or where the prosecution had declined to prosecute.

Profiles from arrested persons must be removed immediately in the following circumstances, namely, where:

(a) the arrestee is a child and is diverted in accordance with the Child Justice Act 75 of 2008;

(b) a decision was made not to prosecute that person;

(c) the person is discharged at a preparatory examination; or

(d) the person is acquitted at his or her trial with the proviso that there are no other criminal investigations outstanding. ${ }^{68}$

In the absence of an application for the removal of arrestees' profiles, certain default periods apply. In the case of an adult, such a profile should be removed within three years; in the case of a child, within12 months.

The Crime Scene Index profiles, as well as those in the Elimination Index, and the Convicted Offenders Index, must be kept indefinitely.

\section{Children}

In the case where a child is convicted, the DNA profile must be expunged in accordance with section 87 of the Child Justice Act 75 of 2008, which provides that:

(1)(a) Where a court has convicted a child of an offence referred to in Schedule 1 or 2 , the conviction and sentence in question fall away as a previous conviction and the criminal record of that child must, subject to subsections (2), (3) and (5), on the written application of the child, his or her parent, appropriate adult or guardian (hereafter referred to as the applicant), in the prescribed form, be expunged after a period of -

(i) five years has elapsed after the date of conviction in the case of an offence referred to in Schedule 1; or

The definition of a DNA reference sample is a buccal or blood sample taken from a person.

68 S 15I(2) of 37 of 2013. 
(ii) 10 years has elapsed after the date of conviction in the case of an offence referred to in Schedule 2, unless during that period the child is convicted of a similar or more serious offence."

In New Zealand, the DNA of young people can be collected only under strict conditions, so very small numbers of profiles have been stored. From 2000 until 2008, only two profiles from ten- to 13-year-olds were loaded on to the database. The retention period for profiles has been expanded by section $26(A)(4)$ of the CIBS Act 1995 . This section provides that a profile may be retained on the database for a period of ten years. ${ }^{69}$

In Scotland, there is a presumption that criminal proceedings should not be taken against a young person unless his or her circumstances, the seriousness of the offence and the available evidence suggest that a criminal trial should be held. Where a young person is convicted, his or her DNA may be retained indefinitely, as is the case for adults. Retention of DNA samples is also allowed after prosecution, when it does not lead to conviction in relation to certain sexual or violent offences. ${ }^{70}$ Given that the age of criminal responsibility in Scotland is eight (however, the Criminal Justice and Licensing (Scotland) Act 2010 precludes the prosecution of anyone under the age of twelve (section 41A Criminal Procedure (Scotland) Act 1995), a not insignificant number of young people have had DNA collected. During March 2009, there were 33 profiles of children under the age of ten on the NDNAD taken by Scottish forces. Thus, DNA retention in Scotland can be predicated on a mere admission by the young person. By contrast, New Zealand does not allow retention of young people's DNA unless the offence has been "proved" in the Youth Court.71

\section{CONCERNS REGARDING EXPUNGEMENT}

In the first Annual Report 2014 of the UK ${ }^{72}$ dealing with the retention and use of biometric material, a number of important issues were raised, namely:

1 In 2013, as part of the Protection of Freedoms Act, the UK database was trimmed in order to remove the details of innocent people. A total number of 1.7 million profiles of children and of adults who had not been convicted of any crime, were deleted.

2 Under the Act, a complicated system of retention rules was introduced to differentiate between certain groups (e.g. persons under 18; those convicted and cautioned, also between low-level offences and crimes such as burglary, rape, murder and terrorism). Yet the new arrangements were so convoluted that even the man responsible for overseeing them, Alastair MacGregor, the UK Biometrics Commissioner, has cast doubt as

\footnotetext{
Campbell and Lynch 2012 http://yjj.sagepb.com/content/12/1/3 8 (accessed 2015-05-06). Ibid.

71 Campbell and Lynch 2012 http://yjj.sagepb.com/content/12/1/3 10 (accessed 2015-05-06).

72 The Annual Report, entitled "Commissioner for the Retention and Use of Biometric Material", made by the Biometrics Commissioner, Alastair R MacGregor QC, to the Home Secretary pursuant to $s 21$ of the Protection of Freedoms Act 2012. This report was submitted to the Home Secretary in November 2014 and a copy was tabled before

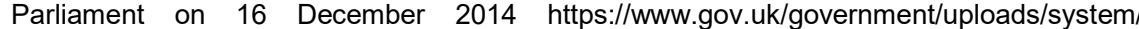
uploads/attachment_data/file/387573/BiometricsAnnualReport201314Print.pdf.
} 
to whether they can work effectively and fairly. He noted that thousands of profiles that should have been deleted are retained on the database, and about 30 have been inadvertently removed (indicating that samples are being mishandled). It seems as if the administration involved in removing a profile is far greater than what had been anticipated.

It is still unclear if South Africa will experience the same challenges in the removal of DNA profiles from the NFDD in future.

\section{IMPLICATIONS OF COLLECTION AND RETENTION OF DNA, AND ACCESS TO A DNA DATABASE ON THE CONSTITUTIONAL RIGHT TO PRIVACY}

Section 7 of the Constitution of the Republic of South Africa, 1996 (the Constitution) confirms that the Bill of Rights is the cornerstone of democracy in South Africa. It enshrines the rights of all people in South Africa and affirms the democratic values of human dignity, equality and freedom. The State must respect, protect, promote and fulfil these rights, subject to limitations as set out in the Bill of Rights itself and in section 36 of the Constitution.

Section 36 specifies that constitutional rights may be limited only in terms of a law of general application, and then only to the extent that the limitation is reasonable and justifiable in an open and democratic society, based on human dignity, equality and freedom. Bearing this in mind, one has to consider how the State's "processing"73 of DNA, referring to its collection, use and retention thereof, could impact the individual's constitutional right to privacy. In this article, we focus on the right to privacy. By limiting the discussion to privacy, the writers are not excluding other fundamental human rights, but merely suggesting that such a discussion will inevitably necessitate an in-depth analysis which falls beyond the scope of this article.

As stated in $S$ and Marper $v$ United Kingdom ${ }^{74}$ ( $S$ and Marper), it is uncontroverted that the fight against crime is dependent on the use of modern scientific techniques, and that the use of DNA analysis offers great advantages to the criminal justice system. Although the court referred to European society in the matter of $S$ and Marper, this statement also holds true for South Africa. It can safely be said that it is universally accepted that DNA profiles can play an important role in the detection and prevention of crime.$^{75}$ At the same time, it is equally true that DNA may contain sensitive

73 This is the definition in $\mathrm{s} 1$ of POPIA, which section came into operation on 11 April 2014:

'"processing' means any operation or activity or any set of operations, whether or not by automatic means, concerning personal information, including -

(a) the collection, receipt, recording, organisation, collation, storage, updating or modification, retrieval, alteration, consultation or use;

(b) dissemination by means of transmission, distribution or making available in any other form; or

(c) merging, linking, as well as restriction, degradation, erasure or destruction of information ..."

74 [2008] ECHR 1169 par 105.

75 Naudé "The Retention of DNA Data and the Private-life Interests of Suspects" 2010 XLII CILSA 213218 
information about the individual, which may affect that individual and/or his family adversely. ${ }^{76}$

In nearly all discussions about the use of DNA in criminal justice systems, the tension between fundamental human rights on the one hand and the legitimate governmental purpose of addressing the societal challenge of crime on the other hand, comes to the fore. ${ }^{77}$ Campbell states that, in many jurisdictions, existing laws regarding collection and storing of DNA are expanding. This is due to the trend to move away from a rights-oriented paradigm towards a more populist and punitive model. This, in turn, is due to the aversion towards risk in political discourse and practice, and the desire to rebalance the criminal justice system in favour of the victim and the wider community. ${ }^{78}$

\section{$7 \quad$ RIGHT TO PRIVACY}

In determining whether an individual's right to privacy has been violated, one must first consider what the right to privacy entails. This is required in order to establish if the law or conduct complained of has indeed infringed upon that right. Thereafter, if an infringement did occur, one must consider whether such an infringement is justifiable under the provisions of section 36 of the Constitution.

Thus, the starting point is defining the term "right to privacy". Prior to the Constitution of the Republic of South Africa 200 of 1993 (the Interim Constitution), the concept of the "right to privacy" was used in the South African common law. Under our common-law regime, the term "privacy" features in the law of delict, in the sense that the right is mostly determined with reference to the boni mores of society. McQuoid-Mason ${ }^{79}$ predicted that the spirit, purpose and objectives of the South African Constitution would play a major role in determining the "new" boni mores of South African society. This is already evident in the enactment of new legislation discussed in this article.

Section 14 of the Constitution affords everyone the right to privacy, which includes the right not to have their person or home searched; their property searched; their possessions seized; or the privacy of their communications infringed. Section 14 consists of two components. The first guarantees a general right to privacy; the second protects the individual against specific infringements of his/her privacy. The general right to privacy in section 14 of the Constitution is, however, not limited only to the specific infringements mentioned in that section. The right to privacy has a much broader

76 Parven "Forensic Use of DNA Information v Human Rights and Privacy Challenges" 2013 17 University of Western Sydney LR 41.

77 In the matter of $R v$ Briggs, the Ontario Court of Appeal found that the best interest of the administration of justice' standard, to be satisfied before DNA collection and comparison could occur, was constitutional in that it requires the court to consider and balance privacy interests against the societal aim of crime control.

78 Campbell 2011 https://www.academia.edu/606506/_Non-Conviction_DNA_Databases_ and_Criminal_Justice_A_Comparative_Analysis 3 (accessed 2015-05-06).

79 In Chaskalson et al Constitutional Law of South Africa (1998)18-3. 
application than the mentioned instances of specific infringements, and the right to privacy is not confined thereby. 80

Section 39 of the Constitution enjoins a court to consider international law when interpreting the Bill of Rights. It is alarming to note that the African Charter on Human and People's Rights ${ }^{81}$ makes no reference to privacy rights.

The meaning of "privacy" is by no means trite, ${ }^{82}$ as the concept may vary depending on the context wherein it is considered. Harms JA, in National Media Ltd $v$ Jooste ${ }^{83}$ stated with reference to Neethling's Law of Personality that the boundary of a right or its infringement remains an objective question, but that the general sense of justice does not require the protection of a fact that the interested party has no wish to keep private.

The right to privacy includes all those personal facts which a person himself determines should be excluded from the knowledge of outsiders. If such information becomes known to outsiders, privacy is infringed. This occurs as an intrusion into the individual's private sphere or disclosure of his/her private facts. ${ }^{84}$ The Constitutional Court held in Investigating Directorate: Serious Economic Offences v Hyundai Motor Distributors (Pty) Ltd; In re Hyundai Motor Distributors (Pty) Ltd v Smit NO,85 that the right to privacy is characterised as lying along a continuum, where the more an individual interconnects with the world outside the sanctity of his/her private sphere, the more the right to privacy becomes moderated.

In Bernstein v Bester NO, ${ }^{86}$ the Constitutional Court stated as follows:

"A very high level of protection is given to the individual's intimate personal sphere of life and the maintenance of its basic preconditions and there is a final untouchable sphere of human freedom that is beyond interference from any public authority. So much so that, in regard to this most intimate core of privacy, no justifiable limitation thereof can take place. But this most intimate core is narrowly construed. This inviolable core is left behind once an individual enters into relationships with persons outside this closest intimate sphere; the individual's activities then acquire a social dimension and the right of privacy in this context becomes subject to limitation."

The Grand Chamber of the ECHR ${ }^{87}$ found that "private life" was a broad term which was not easily defined, but that it encompasses physical and

80 Currie and De Waal The Bill of Rights Handbook 6ed (2005) 295.

81 "Banjul Charter" (Adopted 27 June 1981, OAU Doc. CAB/LEG/67/3 rev. 5, 21 I.L.M. 58 (1982), entered into force 21 October 1986).

82 In Bernstein v Bester NNO 1996 (2) SA 751 (CC), Ackermann J stated: "The concept of privacy is an amorphous and elusive one which has been the subject of much scholarly debate. NM v Smith (Freedom of Expression Institute as Amicus Curiae) 2007 (7) BCLR 751 (CC) par 32 'The academic literature on privacy demonstrates the considerable controversy over the definitional nature and the scope of the right. However, it appears common cause in many jurisdictions that the nature and the scope of the right envisage a concept of the right to be left alone.' And at paragraph [33]: 'Privacy encompasses the right of a person to live his or her life as he or she pleases ..."

$83 \quad$ [1996] 2 All SA 510 (A) 515.

84 Neethling, Potgieter and Visser Neethling's Law of Personality (1996) 270.

852001 (1) SA 545 (CC).

1996 (2) SA 751 (CC) par 77.

$87 \mathrm{~S}$ and Marper $v$ United Kingdom supra par 66 
psychological integrity, and involves multiple aspects of the individual's physical and social identity. The court regarded gender identification, sexual orientation, health, ethnicity, self-image and the development of relationships all to be included herein.

\section{RIGHT TO INFORMATIONAL PRIVACY}

An individual's right to privacy also includes the right to informational privacy. ${ }^{88}$ Stated differently, information protection is a facet of protecting an individual's right to privacy. The gathering and dissemination of private facts pose a direct threat to an individual's privacy. Private facts are those that, if disclosed, will cause mental distress and injury to a person of ordinary feelings and intelligence if placed in similar circumstances, and in respect of which facts there is a will to keep them private. ${ }^{89}$ In protecting the right to privacy, ${ }^{90}$ an individual should retain control over his or her personal information or, at the very least, retain oversight of the data or information material taken from him/her. ${ }^{91}$

Where an individual engages in criminal activity and commits an offence to the detriment of society, then it must be an indication that such a person has stepped away from his intimate sphere where his privacy must be most protected. An arrested person's right to privacy may lawfully be infringed by the arrest, detention, searches, seizures, and taking of certain samples, ${ }^{92}$ including DNA samples. DNA information qualifies as personal facts, worthy of protection through the constitutional right of privacy.

\section{DNA PROCESSING AND PRIVACY}

The taking, retaining and using of an individual's DNA information could most certainly infringe on the individual's right to privacy, as DNA contains sensitive information about an individual and his/her family. ${ }^{93}$

A DNA sample is initially taken to link a particular person to a particular crime, or to exclude a particular person as the perpetrator of a particular crime. DNA can thereafter be retained as a DNA sample and/or as a DNA profile on a database. Although the retention of DNA samples and the retention of DNA profiles are at times treated alike, ${ }^{94}$ these two concepts are distinct and particularly significant when the constitutionality of DNA retention is considered.

88 Mistry v Interim Medical and Dental Council of South Africa 1998 (7) BCLR 880 (CC) par 45-48.

$89 \quad \mathrm{NM} v$ Smith (Freedom of Expression Institute as Amicus Curiae) supra par 34.

90 It is not suggested herein that the right to privacy is the only constitutional right which could be infringed if this caveat is not adhered to.

91 Campbell $2011 \mathrm{https} / / / \mathrm{www}$.academia.edu/606506/_Non-Conviction_DNA_Databases_ and_Criminal_Justice_A_Comparative_Analysis 15 (accessed 2015-05-06).

92 Colb "Innocence, Privacy, and Targeting in Fourth Amendment Jurisprudence" 199696 Columbia LR 1456 1460: "By committing a crime, the individual in effect creates the circumstances that may ultimately relieve the government of its obligation to respect her privacy."

$93 \quad S$ and Marper $v$ United Kingdom supra par 73.

$94 \quad S$ and Marper $v$ United Kingdom supra par 14. 
A DNA sample contains more genetic material than a DNA profile, as discussed earlier. DNA samples contain a wealth of personal information, which could include information such as predisposition to certain diseases, behaviour, physical and mental traits, parentage and genetic relatedness to others. ${ }^{95}$ Kayser ${ }^{96}$ states that DNA samples collected at a crime scene can assist in identifying the offender or the victim, even though their identification is unknown through the process of DNA phenotyping. This process allows for the analysis of a DNA sample to predict the appearance of the donor of the DNA collected at the crime scene. This may include eye, hair and skin colour, body height/stature, age, wrinkles, baldness, hair structure, as well as facial shape. He further proposes that a group of people fitting that description should be requested to provide DNA samples. The use of this type of investigating method will certainly impact the rights of all individuals required to provide samples. The following scenario is an example that might present itself in a small village. The analysis of a DNA sample collected from a crime scene in the village reveals that the perpetrator was a tall male with blue eyes and blond hair and a specific genetic defect. This information then prompts the police to request that all blond men with blue eyes provide DNA samples to determine a match or a familial match in their investigations. As stated, this type of investigation would most definitely violate the right to privacy, unless the DNA samples are provided after informed consent is given.

On the other hand, DNA profiles do not reveal personal information, such as behavioural traits or a propensity for developing a particular disease. However, DNA profiles might still be used to search for and identify possible genetic relatives of an offender, and this might lead to the revealing of a previously unknown or concealed genetic relationship, ${ }^{77}$ which could hugely impact an individual's privacy.

Parven ${ }^{98}$ notes that many forensic DNA databases retain DNA samples from various classes of people, including people who have been acquitted after the conclusion of judicial proceedings, or where the charges were withdrawn or not proceeded with, or even where the DNA samples are from persons excluded from investigation by that very sample. She states that when DNA samples are kept and retained in any database, it is possible to gather the most personal information about any individual (and his or her family). This includes certain behavioural characteristics, ranging from thrillseeking to aggression, and the propensity for aggressive, addictive, or criminal behaviour, and the predisposition to certain disorders and physical and mental diseases. She also acknowledges the scientific criticism of the statement that behavioural characteristics can be read from a DNA sample. However, the caveat remains that it is possible, with ever-evolving knowledge through science that, in future, DNA will be able to show behavioural traits and propensity to commit certain types of offences. ${ }^{99}$

95 Knoetze 'n Regsvergelykende Studie van Deskundige Getuienis in Straf- en Siviele Verhore (Unpublished doctoral thesis, University of the Free State, 2007) 139 and 194.

962015 Forensic Science International: Genetics http://dx.doi.org/10.1016/j.fsigen (accessed 2015-02-03).

97 S and Marper $v$ United Kingdom supra par 39

98201317 University of Western Sydney LR 45.

99 Naudé 2010 XLII CILSA 218. 
Although Lord Steyn in the House of Lords dismissed this argument on the basis that, when such development occurs, judicial or legislative changes can be effected to protect human rights, ${ }^{100}$ the Grant Chamber of the European Court in $S$ and Marper $v$ United Kingdom was of the opposite view, namely that such a concern is legitimate. ${ }^{101}$

Some equate the analysis of a DNA sample with merely identifying an individual, much like the use of fingerprints or photographs. However, ordinary fingerprints provide only identifying information and no more. In the matter of State $v$ Athan, ${ }^{102}$ the court noted that the equation of DNA with physical characteristics like thumbprints is not precise. Alexander CJ, noted as follows: 103

"A person's DNA ... in his saliva, in a droplet of blood, or in a strand of hair, is not, as the majority suggest, equivalent to a person's thumbprint or the cadence of his voice - physical characteristics that truly speak to our identity only. Rather, a person's DNA goes beyond who we are to what we are."

The above quote captures the idea that DNA samples do not merely identify, but also contain personal information. Genetic information is deeply personal ${ }^{104}$ because it does more than merely identify a specific individual. The possibility exists that someone could mine personal and private information from the samples, either through unauthorised third-party access or for malicious, retributive or oppressive purposes. ${ }^{105}$

An arrested person's right to privacy may lawfully be infringed by the arrest, detention, searches, seizures and taking of certain samples. ${ }^{106}$ By retaining the DNA information (after the conclusion of the judicial process), the initial purpose for collecting the DNA is broadened to assist currently in the identification of future or repeat offenders. ${ }^{107}$

According to Campbell, ${ }^{108}$ the subsequent storage of non-consensually collected genetic material arguably affects the right to privacy. The South Africa Supreme Court of Appeal found that a serious infringement of a person's privacy occurs where obtained and retained information is structured in such a way so as to put his or her private behaviour under

$100 S$ and Marper $v$ United Kingdom supra par 19.

101 S and Marper $v$ United Kingdom supra par 71: "The Court maintains its view that an individual's concern about the possible future use of private information retained by the authorities is legitimate and relevant to a determination of the issue of whether there has been an interference. Indeed, bearing in mind the rapid pace of developments in the field of genetics and information technology, the Court cannot discount the possibility that in the future the private-life interests bound up with genetic information may be adversely affected in novel ways or in a manner which cannot be anticipated with precision today."

102 State v Athan 158 P.3d 27 (Wash. 2007).

103 State $v$ Athan supra 44.

$104 S$ and Marper $v$ United Kingdom supra par 25, read with par 72.

105 Suter 2010 23(2) Harvard Journal of Law \& Technology 334 and 335.

106 Colb 199696 Columbia LR 1460: "By committing a crime, the individual in effect creates the circumstances that may ultimately relieve the government of its obligation to respect her privacy."

107 S and Marper $v$ United Kingdom supra par 100

108 Campbell 2011 https://www.academia.edu/606506/_Non-Conviction_DNA_Databases_ and_Criminal_Justice_A_Comparative_Analysis 3 (accessed 2015-05-06). 
scrutiny. ${ }^{109}$ This use of private information to place private behaviour under scrutiny is called information-matching or -profiling. It has two main components, namely the generation of a profile and the application thereof. Profile application is the process of treating persons/ entities in light of this profile. ${ }^{110}$

According to Suter, ${ }^{111}$ very few privacy interests are at stake in DNA profiling, especially for people whose privacy interests are reduced through their behaviour. This does not mean, however, that all retention for purposes of profiling is automatically constitutionally acceptable. The Grand Chamber of the ECHR held that "blanket and indiscriminate" retention of DNA in England and Wales was a violation of the right to privacy and favoured limiting non-conviction DNA retention to serious suspected offences. ${ }^{112}$

Lwin ${ }^{113}$ suggests a sliding scale of the severity of offences and the status of the offender in order to determine whether DNA should remain available on a database. The age of the offender should also play a role, as the retention of DNA of an unconvicted minor can be harmful. ${ }^{114}$

The question whether the indefinite retention of DNA profiles of persons convicted of a certain category of offences infringes on the individual's right to privacy and, if so, whether it was justified under article $8^{115}$ of the European Convention on Human Rights, was recently ruled upon by the English Supreme Court. ${ }^{116}$ The majority of the court ${ }^{117}$ ruled that the retention policy was justifiable under article 8(2) as, inter alia, the principle of proportionality was met. In reaching this decision, the majority answered in the affirmative to each of the questions they used as guiding principles, ${ }^{118}$ namely:

- Whether the objective of the relevant measure is sufficiently important to justify the limitation of a protected right.

- Whether the measure is rationally connected to the objective.

109 National Media Ltd $v$ Jooste supra 516.

110 Bygrave "Minding the Machine: Article 15 of the EC Data Protection Directive and Automated Profiling" 200117 Computer Law and Security Report http://folk. uio.no/lee/publications/ (accessed 2015-05-31) 1724.

1112010 23(2) Harvard Journal of Law \& Technology 331.

$112 \mathrm{~S}$ and Marper $v$ United Kingdom supra par 109-110.

113 "Privacy Issues with DNA Databases and Retention of Individuals' DNA Information by Law Enforcement Agencies" 2010192 Information \& Communications Technology 189191.

$114 S$ and Marper v United Kingdom supra par 122.

115 "Article 8(1) Everyone has the right to respect for his private and family life, his home and his correspondence.

8(2) There shall be no interference by a public authority with the exercise of this right, except such as is in accordance with the law and is necessary in a democratic society in the interests of national security, public safety or the economic well-being of the country, for the prevention of disorder or crime, for the protection of health or morals or for the protection of the rights and freedoms of others."

116 Gaughran v Northern Ireland https://www.supremecourt.uk/cases/docs/uksc-2013-0090judgment.pdf, judgment was given on 13 May 2015

117 Lord Neuberger, Lady Hale, Lord Clarke and Lord Sumption.

118 Gaughran v Northern Ireland par 20 https://www.supremecourt.uk/cases/docs/uksc-20130090-judgment.pdf. 
- Whether a less intrusive measure could have been used without unacceptably compromising the achievement of the objective.

- Whether, balancing the severity of the measure's effects on the rights of the persons to whom it applies against the importance of the objective, to the extent that the measure will contribute to its achievement, the former outweighs the latter. (Or: Whether the infringement is disproportionate to the likely benefit of the impugned measure.)

The dissenting judgment by Lord Kerr, using much the same principles as the majority, but formulating them somewhat less formally, ${ }^{119}$ came to the conclusion that the Irish policy on indefinite retention of DNA profiles needs to be more restrictive, and therefore found that the current retention policy falls foul of article 8 .

In $S$ and Marper $v$ United Kingdom, ${ }^{120}$ the Grand Chamber expressed criticism that the United Kingdom was the only member State to expressly permit indefinite retention of DNA profiles. ${ }^{121}$ However, after an analysis of other member States' laws ${ }^{122}$ in Gaughran $v$ Northern Ireland, Lord Clarke, ${ }^{123}$ concluded that the retention of DNA with no time limit is effectively similar to other State members' retention policies with time limits. He stated that these member States retain such information for long periods until or after the death of the individual.

Further challenges to DNA retention include the purpose for which it will be used, as well as the persons who will have access to the information on the database.

If the obtaining and retention of DNA can, in principle, infringe on the right to privacy, then it follows that the use thereof or dissemination thereof to third parties should also be regarded as unlawful in principle. Neethling ${ }^{124}$ cautioned that the collection and use of personal information in electronic databases create such an enormous threat to the personal rights of the individual that, in the field of delict, the data industry should be held accountable on the basis of strict liability. He further observes that, as an alternative to strict liability, negligence-based liability might also be considered.

Policies determining which state officials and on what basis they would obtain access to a database can also impact the constitutional right of privacy. Easy access to a DNA database could cause an invasion of his or

119 Gaughran v Northern Ireland par 59 https://www.supremecourt.uk/cases/docs/uksc-20130090-judgment.pdf, namely: Is the legislative objective sufficiently important to justify limiting a fundamental right? Are the measures which have been designed to meet it rationally connected to it? Are they no more than are necessary to accomplish it? Do they strike a fair balance between the rights of the individual and the interests of the community?

120 Supra 1169.

121 Supra par 47

122 Conveniently set out in annexure B to the judgment at 24-26 thereof.

123 Gaughran v Northern Ireland par 39-46 https://www.supremecourt.uk/cases/docs/uksc2013-0090-judgment.pdf.

124 Neethling “Aanspreeklikheid vir Nuwe Risiko's: Moontlikhede en Beperkinge van die SuidAfrikaanse Deliktereg" 2002 THRHR 583584. 
her own privacy or his or her family's privacy. JC Hoeffel, ${ }^{125}$ noted as follows regarding DNA profiling:

"Imagine a society where the government had samples of tissue and fluid from the entire community on file and a computerized databank of each individual's DNA profile. Imagine then that not only law enforcement officials, but insurance companies, employers, schools, adoption agencies, and many other organizations could gain access to those files on a 'need to know' basis or on a showing that access is 'in the public interest'. Imagine then that an individual could be turned down for jobs, insurance, adoption, health care, and other social services and benefits on the basis of information contained in her DNA profile, such as genetic disease, heritage, or someone else's subjective idea of a genetic 'flaw'."

The retention of DNA profiles of juveniles is also problematic. In the case of $R \vee R C,{ }^{126}$ the Supreme Court of Canada found that the retention on the national databank of a DNA sample of a juvenile first-time offender violates his right to informational privacy. The Grand Chamber stated as follows in $S$ and Marper: ${ }^{127}$

"The Court further considers that the retention of the unconvicted persons' data may be especially harmful in the case of minors such as the first applicant, given their special situation and the importance of their development and integration in society. The Court has already emphasised, drawing on the provisions of Article 40 of the UN Convention on the Rights of the Child of 1989, the special position of minors in the criminal-justice sphere and has noted in particular the need for the protection of their privacy at criminal trials (see T. v. the United Kingdom [GC], no. 24724/94, §§ 75 and 85, 16 December 1999). In the same way, the Court considers that particular attention should be paid to the protection of juveniles from any detriment that may result from the retention by the authorities of their private data following acquittals of a criminal offence. The Court shares the view of the Nuffield Council as to the impact on young persons of the indefinite retention of their DNA material and notes the Council's concerns that the policies applied have led to the over-representation in the database of young persons and ethnic minorities, who have not been convicted of any crime."

The processing of DNA in the South African context and the protection of the right to privacy will be discussed in light of the challenges mentioned above.

The question whether the processing of information of an individual infringes the individual's right to privacy is factual and will be determined by courts on a case-to-case basis. ${ }^{128}$ The privacy of the individual may be infringed by the collection and storing of personal information, which amount to an intrusion of privacy, as well as by the use and communication of personal information, which amount to a disclosure of privacy.

\footnotetext{
125 "The Dark Side of DNA Profiling: Unreliable Scientific Evidence Meets the Criminal Defendant" 199042 Stanford LR 465 533-534.

126 [2005] 3 S.C.R. 99, 2005 SCC 61.

127 Supra par 124.

128 S v Makwanyane 1995 (6) BCLR 655 (CC) 708 par 104.
} 


\section{LIMITATION OF CONSTITUTIONAL RIGHTS BY LAW OF GENERAL APPLICATION}

For the purpose of this analysis, it is accepted that the taking and storing of a DNA profile infringes on an individual's right to privacy. As the right to privacy is not absolute, the question to be answered is whether this infringement is justifiable in terms of section 36 of the Constitution. The Constitutional Court emphasised the interdependency between the common law and the constitutional right to privacy, ${ }^{129}$ but stated that the test whether an invasion of privacy is unlawful at common law is a single inquiry, whereas under the Constitution a two-fold inquiry is required.

We acknowledge that the common-law right of personality can be limited by the legitimate interests of others and the public interest, 130 but fundamental rights cannot be infringed just because the general welfare will be served thereby. Section 36 of the Constitution determines that rights may be limited only in terms of a law of general application, and then only to the extent that the limitation is reasonable and justifiable in an open and democratic society based on human dignity, equality and freedom.

The Criminal Law (Forensic Procedures) Amendment Act 37 of 2013 and its Regulations (Forensic DNA Regulations, 2015) constitute a law of general application. The purpose of this Act is to pursue the legitimate aims of detection, prevention of crime and the identification of future offenders. While this Act is concerned with the establishment of a national DNA database, the Protection of Personal Information Act 4 of 2013 (POPIA) intends to regulate DNA processing. ${ }^{131}$

POPIA defines personal information as information relating to an identifiable, living, natural person and, where it is applicable, an identifiable, existing juristic person, including, but not limited, to certain information. ${ }^{132}$

POPIA defines the term "biometrics" as a technique of personal identification that is based on physical, physiological or behavioural

129 Bernstein $v$ Bester NNO supra 787ff.

130 See Neethling et al Neethling's Law of Personality $239 f f$.

131 S 1, s 39-54 and s 112-113 came into operation on 11 April 2014. On 19 May 2015, the Deputy Minister of Justice and Constitutional Development issued a statement that an agreement on the salary structure of the Information Regulator had been reached and that the nomination process would now be put into place. This, in turn, will result in the rest of POPIA being put into operation soon. Jeffery "Address by Deputy Minister of Justice and Constitutional Development, during the budget debate vote 21, Parliament (19/05/2015)" (20 May 2015) http://www.polity.org.za/article/sa-john-jeffery-address-by-deputy-minister-ofjustice-and-constitutional-development-during-the-budget-debate-vote-21-parliament19052015-2015-05-20 (accessed 2015-05-29)

132 (a) Information relating to the race, gender, sex, pregnancy, marital status, national, ethnic or social origin, colour, sexual orientation, age, physical or mental health, well-being, disability, religion, conscience, belief, culture, language and birth of the person; (b) information relating to the education or the medical, financial, criminal or employment history of the person; (d) the biometric information of the person; (e) the personal opinions, views or preferences of the person; $(\mathrm{g})$ the views or opinions of another individual about the person; and $(h)$ the name of the person if it appears with other personal information relating to the person or if the disclosure of the name itself would reveal information about the person. 
characterisation, including blood typing, fingerprinting, DNA analysis, retinal scanning and voice recognition.

The purpose of POPIA is set out in section 2 as follows: ${ }^{133}$

The purpose of this Act is to -

(a) give effect to the constitutional right to privacy, by safeguarding personal information when processed by a responsible party, subject to justifiable limitations that are aimed at - (i) balancing the right to privacy against other rights, particularly the right of access to information; and (ii) protecting important interests, including the free flow of information within the Republic and across international borders;

(b) regulate the manner in which personal information may be processed, by establishing conditions, in harmony with international standards, that prescribe the minimum threshold requirements for the lawful processing of personal information;

(c) provide persons with rights and remedies to protect their personal information from processing that is not in accordance with this Act and

(d) establish voluntary and compulsory measures, including the establishment of an Information Regulator, to ensure respect for and to promote, enforce and fulfil the rights protected by this Act."

It can be gleaned from both the provisions of the Criminal Law (Forensic Procedures) Amendment Act and POPIA, that the Legislator was well aware that processing personal information places the right to privacy in danger of possible infringement. It follows that, should an infringement of the individual's right to privacy occur, it is in terms of a law of general application.

The second component of the enquiry, namely to establish if this law of general application is reasonable and justifiable in an open and democratic society, based on human dignity, equality and freedom, will now be discussed.

The right to privacy and the opposing interests or rights must be carefully weighed against one another. Section 36(1) of the Constitution states a nonexhaustive list of key factors, which must be used in conjunction with other relevant factors, ${ }^{134}$ to consider if the limitation of a right is justifiable:

(a) the nature of the right;

(b) the importance of the purpose of the limitation;

(c) the nature and extent of the limitation;

(d) the relation between the limitation and its purpose; and

(e) less restrictive means to achieve the purpose.

In South Africa, the combating of crime is a legitimate aim of the State, and it would qualify as a "pressing social need" 135 for the State to address. DNA as an important law enforcement tool. ${ }^{136}$ Its collection and retention is rationally connected to a legitimate governmental purpose. The processing

133 This section is not yet in operation.

134 S v Manamela (Director-General of Justice Intervening) 2000 (5) BCLR 491 (CC) 508.

$135 S$ and Marper $v$ United Kingdom supra par 101.

136 Campbell 2011 https://www.academia.edu/606506/_Non-Conviction_DNA_Databases and_Criminal_Justice_A_Comparative_Analysis 10 (accēssed 2015-05-06). 
of DNA, in terms of the amendment Act, appears prima facie to be proportionate to this aim.

As noted earlier, the information contained in a database must be protected against misuse and abuse. ${ }^{137}$ The Court in $S$ and Marper ${ }^{138}$ highlighted that certain factors, such as the nature and gravity of the offence of which a person is suspected, and the age of the suspect should play some role in determining reasonableness.

It is therefore prudent that section $36 \mathrm{~B}(2)(\mathrm{b})$ of the Criminal Procedure Act determines that any person who uses, or who allows the use, of non-intimate samples of information derived from such samples for any purpose other than the mentioned purposes is guilty, liable on conviction to a fine or imprisonment not exceeding 15 years.

Storage of data must be proportionate to the purpose of the retention. The test for proportionality must, of necessity, include the length of the storage of the data. ${ }^{139}$

\section{CONCLUSION}

The Criminal Law (Forensic Procedures) Amendment Act 37 of 2013 has, as yet, not been tested in South African courts. Neither has the new POPIA, as most of its sections are not yet in operation. Parliament was proactive in enacting both these Acts and giving consideration to the constitutional right to privacy before South African courts have to grapple with DNA processing.

These Acts will create a legislative framework for the collection, storing, use and, ultimately, lengthy retention of DNA, which will be utilised in such a manner that it would satisfy the legitimate governmental purpose of combating crime, while, at the same time, affording some protection to the right to privacy. Although the writers are prima facie of the opinion that the individual's right to privacy is not violated by these Acts, only time will tell whether this opinion is correct.

37 Data Protection Convention of 1981 article 7.

138 Supra par 119.

139 S and Marper v United Kingdom supra par 107. 